\title{
Sosiologi Pedesaan di Era Corona Virus 19
}

\author{
Johan Wahyudi Adiluhung \\ Guru Sosiologi SMA Muhammadiyah 2 Sidoarjo \\ Johan.adiluhung@gmail.com
}

Received: 25 Juni 2020; Revised: 10 Juli 2020; Accepted : 15 Juli 2020; Published : Agustus 2020; Available online : Agustus 2020.

\begin{abstract}
Rural sociology is one branch of sociology itself. Historically, it developed after the humanitarian aspects of agriculture gained attention in the United States, namely in 1908. The study began with the writings of a Christian priest who was in the socio-economic conditions of rural communities in northern America. Through this article, they solved the problems that arose in rural areas as a result of the birth of industry, which caused some rural areas to be abandoned. In addition, the end of the exploration of new areas to the West end of the 19th century. In the 1920s, courses on the subject of rural life began to be studied at various universities, especially at The American Sociological Society.
\end{abstract}

Keywords: Rural Sociology, Village, Corona Virus 2019 


\section{Pendahuluan}

Sosiologi pedesaan adalah salah satu cabang dari sosiologi itu sendiri. Secara historis, ia berkembang setelah segi-segi kemanusiaan dari pertanian mendapat perhatian di Amerika Serikat, yaitu pada tahun 1908. Kajiannya bermula dari tulisan seorang pendeeta Kristen yang kondisi social ekonomi masyarakat pedesaan di bagian utara Amerika. Lewat tulisan itu mereka memecahkan persoalan yang timbul di pedesaaan akibat lahirnya industry, sehingga menyebabkan sebagian daerah pedesaan menjadi terbengkalai. Selain itu, berakhirnya masa penjelajahan daerah baru ke daerah Barat akhir abad 19. Pada tahun 1920-an, mata kuliah tentang persoalan kehidupan pedesaan mulai dikaji di berbagai universitas terutama di The American Sociological Society.

Sosiologi Pedesaan dipahami sebagai penerapan teori-teori (umum) sosiologi dalam mempelajari masyarakat. Smith dan Zophf dalam Bahrein (1996) mengemukakan bahwa sosiologi pedesaan adalah sosiologi dari kehidupan pedesaan (sociologi of rural life). Studi ini adalah suatu pengetahuan yang sistematik sebagai hasil, penerapan metode ilmiah dalam upaya mempelajari masyarakat pedesaan, struktur dan organisasi sosialnya, sistem dasar masyarakat, dan proses perubahan sosial yang terjadi. Pendapat Smith dan Zophf didukung oleh Wiriatmaja dimana sosiologi pedesaan adalah ilmu yang mencoba mengkaji hubungan anggota masyarakat di dalam dan antara kelompok-kelompok di lingkungan pedesaan.

Sementara itu Rogers dkk dalam Bahrein (1996), melihat sosiologi pedesaan sebagai ilmu yang mempelajari prilaku spasial (fenomena) masyarakat dalam setting pedesaan yang berhubungan dengan kelompoknya. Sosiologi pedesaan lebih sering dipakai dalam pemecahan masalah masyarakat pedesaan. Oleh karena itu, studi ini lebih berorientasi pada proses perubahan sosial dan pemecahan masalah.

Tidak jauh berbeda jauh dengan Galeski (1972), sosiologi pedesaan disebutnya sebagai studi yang cenderung deskriptif, karena pedesaan merupakan daerah pertanian, terdapat pola-pola pertanian dan bertani, kehidupan keluarga di desa, tingkat kehidupan dan perkembangan penduduknya, struktur sosial yang berhubungan dengan pekerjaan, lembaga-lembaga pedesaan, adat dan kebiasaan penduduk dan 
sebagainya. Bahkan dewasa ini sosiologi pedesaan ada yang menganggap sama dengan sosiologi pertanian (sociology of agriculture). Namun keduanya memiliki perbedaan, yaitu sosiologi pertanian cenderung memfokuskan upaya sosiologi bagi masyarakat desa yang menggeluti pertanian saja. Sedang sosiologi pedesaan menekankan studinya pada masyarakat pedesaan tanpa mempersoalkan hubungan mereka dengan usaha tani. Karena banyaknya masyarakat desa yang tidak lagi secara lansung terlibat pada sektor primer, tetapi sudah berkembang ke sektor sekunder.

\section{PEMBAHASAN}

\section{Pedesaan di Indonesia}

Kata "pedesaan" sepadan dengan kata rural dalam bahasa Inggris. Dalama pemakainnya sehari-hari definisi dari perkataan tersebut sulit dikemukakan secara utuh, karena konsep pedesaan berbeda dari satu kawasan ke kawasan lain, dan berbeda pula dari satu negara ke negara lain. Dari segi geografis, Bintarto (1989) mengemukakan bahwa desa adalah suatu hasil perpaduan antara kegiatan sekelompok manusia dengan lingkungannya. Hasil dari perpaduan itu dapat dilihat pada unsur-unsur fisiografi, sosial dan ekonomi, politik dan kultural yang saling berinteraksi antara unsur tersebut dan juga dalam hubunganya dengan daerah-daerah lain. Sementara itu Sutardjo Kartohadikusumo menyatakan bahwa desa adalah satu kesatuan hukum dimana bertempat tinggal suatu masyarakat yang berkuasa mengadakan pemerintahan sendiri.

Paul H. Landis dalam Jefta (1995) mencoba memberikan batasan pengertian pedesaan sebagai berikut;

1. Untuk maksud statistik, pedesaan adalah suatu tempat dengan jumlah penduduk kurang dari 2.500 orang

2. Dari kajian psikologi sosial, pedesaan adalah daerah dimana pergaulan masyarakatnya ditandai oleh derajat intimitas yang tinggi

3. Dari kajian ekonomi, pedesaan adalah daerah dimana pusat perhatiannya pada bidang perhatian.

Di Indonesia, batasan Landis kurang tepat dipakai, sebab jumlah penduduk satu desa di Jawa misalnya melebihi 11.445 orang, tetapi keadaannya masih bersifat pedesaan. Sebaliknya, kondisi dikota-kota besarpun mencirikan sifatsifat pedesaan. 


\section{Sosiologi Pedesaan di Era Covid-19}

Wabah virus corona kini menjadi realitas sosial yang harus dihadapi masyarakat dunia, khususnya bagi bangsa Indonesia. Tidak dipungkiri bahwa dengan beredarnya kabar virus corona yang telah menjangkiti Indonesia berdampak pada sikap masyarakat yang menjadi lebih over-protektif terhadap lingkungan sekitarnya. Ketakutan terhadap virus corona akan memberikan pengaruh terhadap sikap sosial masingmasing individu. Kita akan lebih mudah menaruh curiga pada orang yang batuk, bersin, atau terlihat pucat di sekitar lingkungan kita. Kita akan lebih cenderung memutuskan menjauh ketimbang menanyakan kabar atau sekadar menunjukkan bentuk kepedulian kecil lainnya. Asumsi-asumsi ini sifatnya memang masih spekulatif, tetapi tidak menutup kemungkinan bahwa ancaman virus corona ini tidak hanya akan merenggut kesehatan seseorang tetapi juga merenggut rasa sosial kita terhadap sesama.

Ketidakmampuan kita dalam mengelola rasa curiga, takut, sikap overprotektif dalam merespons isu corona ini memiliki potensi untuk merusak hubungan sosial dengan individu lain. Apalagi, jika kita hidup dan aktif dalam lingkungan pergaulan di kantor, sekolah, masyarakat, bahkan keluarga. Adalah hal yang manusiawi ketika kita mulai memberikan respons antisipatif dalam melihat situasi. Namun, ada etika sosial yang perlu dijunjung tinggi dan dipelihara agar hubungan dengan sesama tetap terjaga. Sebagai contoh, jika kita tengah mengalami kondisi badan yang kurang fit segera berobat ke dokter. Segera gunakan alat proteksi diri seperti masker jika hendak bersosialisasi kendati dokter tidak memberi diagnosis positif corona atau penyakit parah lainnya. Selain itu, kita juga perlu memiliki inisiatif untuk mengurangi interaksi bersentuhan dengan orang lain seperti berjabat tangan dan berpelukan.

Hal ini dilakukan sebagai upaya "sadar diri" dan memastikan orang lain aman dan nyaman bersama kita. Lain halnya jika kita dalam kondisi sehat dan menemukan orang di sekitar kita yang terlihat tidak baik-baik saja. Etika sosial kita terhadap mereka bisa ditunjukkan dengan membujuk mereka untuk pergi ke klinik atau rumah sakit terdekat untuk periksa, atau sekadar bertanya kabar dan memberikan nasihat secara baik untuk menjaga kesehatan. Tindakan-tindakan sederhana tersebut kita lakukan dengan tetap menjaga kehati-hatian. Hal ini 
dilakukan sebagai wujud antisipasi kolektif, tindakan melindungi diri dengan memastikan orang-orang di sekitar kita juga terlindungi. Sikap seperti ini adalah cermin dari etika sosial kita terhadap sesama, bahkan dalam kondisi genting sekalipun. Wabah corona menjadi ketakutan kita bersama. Namun, jangan sampai wabah ini merenggut cara kita memanusiakan sesama. Selain mengedepankan aspek materiil seperti menjaga perilaku hidup sehat, mengenakan masker, berolahraga rutin, dan asupan bergizi, aspek non materiil juga perlu dipelihara seperti etika sosial kita terhadap sesama yang tercermin dari sikap peduli, saling pengertian, dan aware dengan lingkungan sosial kita.

Corona mungkin bisa merenggut nyawa manusia, tetapi ada satu hal yang tidak bisa direnggut olehnya; kemanusiaan. Sebenarnya rasa cemas dan ketakutan pada diri masyarakat atas wabah virus corona adalah hal yang manusiawi. Namun hal ini jika tidak diatasi, secara sosiologis akan menimbulkan disorganisasi dan disfungsi sosial di masyarakat. Perlu dipahami, ciri otentik dari masyarakat adalah kedinamisan dalam perubahan di tatanan sosialnya saat mendapat stimulus tertentu - dalam hal ini rasa takut atas wabah virus corona. Kondisi perubahan ini bersifat interpenden. Artinya, sulit untuk dapat membatasi perubahan-perubahan pada masyarakat karena masyarakat merupakan mata rantai yang saling terkait. Oleh karena itulah, diorganisasi dan disfungsi sosial menjadi suatu keniscayaan.

Disorganisasi pada masyarakat akan mengarah pada situasi sosial yang tidak menentu. Sehingga dapat berdampak pada tatanan sosial di masyarakat. Wujud nyatanya berupa prasangka dan diskriminasi. Hal ini bisa kita lihat bagaimana reaksi masyarakat saat ada warga Indonesia positif terjangkit virus corona. Misalnya, ada masyarakat yang mulai membatasi kontak sosialnya untuk tidak menggunakan angkutan umum, transportasi online, dan menghindari berinteraksi diruang sosial tertentu (seperti pasar dan mall) karena kuatir tertular virus corona. Prasangka masyarakat ini tentu memiliki alasan logis. Sebab dalam perspektif epidemiologi, terjadinya suatu penyakit atau masalah kesehatan tertentu disebabkan karena adanya keterhubungan antara pejamu (host) dalam hal ini manusia atau makhluk hidup lainnya, penyebab (agent) - dalam 
hal ini suatu unsur, organisme hidup, atau kuman infektif yang dapat menyebabkan terjadinya suatu penyakit, serta ingkungan (environment) - dalam hal ini faktor luar dari individu yang dapat berupa lingkungan fisik, biologis, dan sosial. kondisi keterhubungan antara pejamu, penyebab dan lingkungan adalah suatu kesatuan yang dinamis yang jika terjadi gangguan terhadap keseimbangan hubungan diantaranya, inilah yang akan menimbulkan kondisi sakit.

Berawal dari prasangka, akhirnya dapat muncul sikap diskriminasi. Sikap diskriminasi yang paling nyata terjadi berupa kekerasan simbolik. seperti tidak mau menolong orang lain secara kontak fisik langsung dengan orang yang diduga terjangkit virus corona. Selain disorganisasi sosial, disfungsi sosial juga terjadi akibat rasa takut atas wabah virus corona. Disfungsi sosial membuat seseorang atau kelompok masyarakat tertentu tidak mampu menjalankan fungsi sosialnya.individu sebagai makhluk sosial mulai membatasi kontak sosialnya dengan tidak mau menolong orang yang belum tentu positif terjangkit virus corona.

Disfungsi sosial membuat individu justru mengalami gangguan pada kesehatannya. Dalam perspektif sosiologi kesehatan, kondisi sehat jika secara fisik, mental, spritual maupun sosial dapat membuat individu menjalankan fungsi sosialnya. Jika kondisi sehat ini terganggu - dalam kasus ini terganggu sosialnya. Tentu individu ini dinyatakan sakit. Kondisi sakit di sini sebagaimana yang dikemukakan Talcott Parsons (1951) dalam bukunya "The Social System", bahwa ia tidak setuju dengan dominasi model kesehatan medis dalam menentukan dan mendiagnosa individu itu sakit. Bagi Parsons, sakit bukan hanya kondisi biologis semata, tetapi juga peran sosial yang tidak berfungsi dengan baik. Parsons melihat sakit sebagai bentuk perilaku menyimpang dalam masyarakat. Alasannya karena orang yang sakit tidak dapat memenuhi peran sosialnya secara normal dan karenanya menyimpang dari norma merupakan suatu yang konsensual. Lalu apa wujud kondisi sakit secara sosial ini? Diorganisasi dan disfungsi sosial.

Terjadinya diorganisasi dan disfungsi sosial akan memicu efek bola salju (snowball effect) pada sektor kehidupan lainnya. Efek paling nyata adalah bidang ekonomi. Dampak dari diorganisasi dan disfungsi sosial karena wabah virus corona, membuat individu atau kelompok masyarakat mengalami 
penurunan produktivitas kegiatan ekonominya. Mulai dari kegiatan produksi, hingga kegiatan konsumtif. Penurunan produktivitas kegiatan ekonomi warga negara akan berdampak pada tingkat pertumbuhan ekonomi negara. Maka untuk itu, perlu upaya yang terintegrasi dalam pendekatan penanganan wabah virus corona ini. Wabah virus corona yang mempunyai dampak,menciptakan kematian, penyakit, kekurang nyamanan, kekurangpuasan, serta kemelaratan.

Dengan dampak yang ditimbulkan oleh wabah Virus ini yang sangat lah serius, Oleh karena itulah untuk menanggulangi wabah virus corona tidak hanya dilakukan dengan intervensi dibidang kesehatan saja, tetapi harus dilakukan secara terpadu (lintas sektoral), seperti melakukan Intervensi sosial Intervensi sosial dilakukan sebagai upaya mengantisipasi kondisi masyarakat yang disorganisasi dan disfungsi sosial. Dengan adanya intervensi sosial, diharapkan dapat memperbaiki fungsi sosial atau mencegah individu atau kelompok masyarakat tertentu mengalami disfungsi akibat fenomena wabah virus corona. Intervensi sosial yang dapat dilakukan oleh negara, antara lain: memberikan pelayanan sosial, pelayanan fisik, pelayanan psikososial, pelayanan ketrampilan dalam mencegah agar tidak terjangkit virus corona atau ketrampilan hidup sehat, pelayanan spiritual, pelayanan pendampingan, pelayanan advokasi,

\section{Psikologi Sosial Pedesaan di Era Covid} 19

Dahulu entitas desa sering digambarkan sebagai teritori yang paling rentan terhadap wabah baik penyakit yang merusak fisik manusia ataupun wabah hama yang merusak komoditas pangan. Masyarakat desa di Pulau Jawa terutama Jawa Timur dan Jawa Tengah telah akrab dengan "pagebluk" di kala wabah penyakit melanda dan istilah "paceklik" ketika komoditas pangan sulit tersedia. Sejarah di Indonesia menunjukkan berbagai macam penyakit telah mematikan kehidupan desa seperti kolera dan pes. Sejarah di ranah global juga memperlihatkan bahwa wabah seringkali muncul pertama kali di desa lalu merusak dengan cepat kehidupan warga desa. Virus ebola yang mewabah di Afrika sebenarnya merupakan sebuah nama sungai di sekitar desa Yambuku, Zaire yang penduduknya terinfeksi virus tersebut (CDC, 2018). 
Desa-desa di wilayah Alaska, Amerika Serikat juga menerima dampak buruk ketika Spanish Flu mewabah pada 1918-1919. Fakta sejarah wabah di Desa Eyam, Inggris 300 tahun lalu bahkan hingga hari ini menjadi pembelajaran kebijakan isolasi dan karantina (Massad et al., 2004). Desa Eyam mereka harus kehilangan 267 warga desa, padahal jumlah total mereka sebelum wabah adalah 350 orang. Tentu, desa-desa di era masa kini seharusnya lebih kuat melawan pandemi dengan sejarah panjang tersebut. Desa seringkali dimitoskan rawan dari berbagai ancaman terutama dari segi kesehatan, pendidikan, dan ekonomi. Sebut saja masih ada anggapan masyarakat desa yang sakit-sakitan, terbelakang, dan miskin. Dalam konteks Indonesia mestinya anggapan tersebut sudah harus pudar ketika institusi desa menjadi desa yang telah memiliki sumber daya yang mumpuni.

Tentu hari ini desa harus menjadi benteng untuk melindungi rakyat di tengah gempuran wabah yang datang terutama desa pasca implementasi UU Desa bersama limpahan dana desanya. Dalam konteks terkini pun entitas desa menjadi benteng dengan kebijakan microlockdown. Alhasil desa tetap menjadi entitas komunitas lokal yang krusial dalam masa new normal. Desa menunjukkan kekuatan mereka dengan melakukan lockdown mandiri untuk melawan balik wabah Covid-19. Mereka berani mendahului kebijakan sentral dari pemerintah pusat karena benar-benar memahami harapan dan kebutuhan masyarakatnya sendiri. Selain itu berbagai desa juga melakukan usahausaha preventif untuk mempertahankan wilayahnya agar tetap steril dari wabah dan tetap memiliki daya tahan di tengah lesunya ekonomi akibat wabah. Mereka menggunakan sumber daya sendiri untuk melakukan pembagian jamu ke warga, memberikan sembako ke warga yang terdampak, penyemprotan desinfektan, mendirikan pos jaga untuk memantau pergerakan warga hingga membuat dan mendistribusikan masker buatan warga desa.

Warga desa bukanlah penduduk yang kebal virus, namun mereka harus tetap memproduksi hasil pertanian untuk menghidupi diri dan menyangga kehidupan kota. Sementara, hingga saat ini belum ada kebijakan yang terlihat mumpuni untuk menahan penyebaran pandemi. Kota besar istirahat sementara waktu hingga pandemi berlalu, sementara desa dipacu untuk tetap 
memutarkan sendi-sendi ekonomi supaya bahan pangan penyangga kehidupan tidak terhenti. Menghadapi beratnya beban ini, pemerintah membekali desa dengan protokol relawan desa lawan Covid-19. Sayangnya, protokol yang bersifat relawan ini tak ada tambahan anggaran khusus yang disematkan, karena relawan desa diharapkan dapat diatur bekerja tanpa digaji. Protokol ini digulirkan melalui Permen Desa, PDT, dan Transmigrasi No. 8/2020 untuk menjaga dua komponen krusial, yaitu memperkuat sendi-sendi ekonomi melalui PKTD dan penguatan kesehatan masyarakat desa mencegah penyebaran Covid-19.

Melalui relawan desa lawan Covid-19 diharapkan mampu mendukung penyebarluasan kebijakan pemerintah untuk memutus rantai penyebaran virus secara terorganisir hingga desa. Relawan desa merupakan bagian dari pemerintah desa ditambah pendamping yang ada di desa, tokoh masyarakat, karang taruna, PKK, serta kader desa lainnya. Ada sepuluh tugas yang diatur oleh pemerintah yang bisa dilaksanakan oleh relawan. Kesepuluh tugas yang praktis tanpa bekal biaya itu hanya berharap menunggu peralihan sebagian anggaran dari dana desa yang telah digunakan untuk padat karya. Kesepuluh tugas relawan tersebut (1) Memberikan edukasi ke masyarakat tentang Covid-19; (2) Mendata penduduk rentan sakit; (3) Menyiapkan Ruang Isolasi Covid-19 di sesa; (4) Menyemprotkan disinfektan dan menyediakan tempat cuci tangan dengan sabun dan air mengalir atau cairan pembersih tangan di tempat umum; (5) Menyediakan alat kesehatan untuk deteksi dini, perlindungan, dan pencegahan penyebaran wabah yang dikoordinasikan dengan Puskesmas atau tenaga-tenaga kesehatan di pedesaan; (6) Menyediakan alat deteksi dini non medis berupa daftar isian/formulir sebagai pedoman wawancara atau yang diisi oleh warga sebagaimana contoh terlampir; (7) menyediakan informasi nomor telepon rumah sakit rujukan, nomor telepon ambulans, dan lain-lain; (8) mendirikan Pos Jaga Gerbang Desa (24 jam); (9) Memastikan tidak ada kerumunan banyak orang; (10) Penyiapan dan penanganan logistik untuk kepentingan warga desa yang menjalani isolasi serta penyiapan logistik untuk situasi dan kondisi yang darurat, baik melalui BUMDes, lumbung desa, dan lain-lain. 
Dengan aturan ini, relawan komunitas desa menjadi penyangga kota. Pertama, menangani pemudik yang pulang kampung dengan potensi virus Covid-19 yang dibawanya. Kedua, menjaga kesehatan warga melalui menjaga kebersihan dan jaga jarak, namun bukan menghentikan aktivitas seperti yang berlangsung di kota. Ketiga, menjaga ketahanan pangan tidak hanya bagi desa sekaligus menyangga kehidupan kota yang tengah tertidur. Melaksanakan aturan ini, relawan desa dapat memanfaatkan infrastruktur sosial yang telah berdiri atau kegiatan yang telah membudaya di warga desa. Romer (2012) menegaskan bahwa infrastruktur sosial bermanfaat dalam proses pembangunan. Infrastruktur sosial ini merupakan endowment atau hal yang sudah melekat di dalam suatu komunitas terkecil seperti desa. Untuk kasus di Indonesia, infrastruktur sosial tercermin pada Data Potensi Desa (Podes) 2018.

Relawan desa memiliki modal infrastruktur sosial yang dapat digerakkan, meski terkendala anggaran desa yang terbatas. Seperti pembuatan ruang isolasi dapat mengalihfungsikan poskesdes di 35.750 desa. Sementara, pendirian pos jaga yang dapat dilakukan secara gotong royong atau memanfaatkan pos keamanan lingkungan (poskamling) telah tersedia di 46.752 desa. Bahkan, 38.702 desa mengaktifkan sistem keamanan lingkungan berasal dari inisiatif warga, seperti portal desa. Selain itu, penyiapan logistik untuk warga sedang mengalami musibah pada dasarnya sudah menjadi kebiasaan di desa dalam bentuk gotong royong. Relawan desa hanya perlu membangkitkan pelaksanaan kegiatan ini melalui RT/RW. Kegiatan ini ada di 67.760 desa yang warganya sebagian besar warga terlibat.

Pada kegiatan sosialisasi, relawan desa dapat melibatkan tenaga kesehatan yang tinggal di desa untuk sosialisasi pandemi Covid-19. Rata-rata ada 5 orang tenaga kesehatan yang tinggal di desa, mulai dari tenaga kesehatan masyarakat, perawat, bidan, hingga dokter. Tenaga kesehatan akan lebih mudah mensosialisasikan program pencegahan Covid-19 sesuai protokol kesehatan WHO. Semua infrastruktur sosial ini dapat dijadikan amunisi awal, mengingat keterbatasan anggaran yang tersedia di desa. Selanjutnya, memastikan protokol desa lawan Covid-29 dapat berjalan, Ketua Gugus Tugas di Pemerintahan Tingkat II, yaitu Bupati dan Wali Kota perlu mengkoordinasikan semua 
relawan desa di wilayahnya. Gugus tugas ini telah diatur melalui Keputusan Presiden Republik Indonesia Nomor 7 Tahun 2020 Tentang Gugus Tugas Percepatan Penanganan Coronavirus Disease 2019 (Covid-19). Koordinasi ini untuk memastikan desa kuat menghadapi pandemi, sekaligus memastikan perekonomian tetap berjalan dan pertanian tetap diproduksi untuk menyangga ketahanan pangan semua lini.

Sekarang, sendi-sendi ekonomi masing-masing wilayah telah dibebankan pada desa dengan segala kekurangan. Dengan protokol relawan desa yang telah disiapkan, semoga dapat menahan penyebaran Covid-19 melalui transmisi lokal. Pada kondisi ini, sebaiknya pemerintah (melalui Ketua Gugus Tugas) perlu menjamin bahwa protokol relawan desa ini dapat menguatkan warga desa melawan pandemi. Jika tidak, meski telah diterapkan dengan ketat, menjadikan warga desa semakin rentan seperti tanpa perlindungan. Karena pemerintah telah memaksakan perekonomian desa harus tetap berjalan untuk menyangga kehidupan perkotaan yang tengah diistirahatkan.

Desa semakin terbebani saat pandemi Covid-19 terjadi, terlebih dengan pulangnya pekerja urban yang telah sampai di kampung halaman karena membawa kecemasan terjadinya transmisi lokal virus corona. Sekarang, kota besar telah banyak dikunci dengan pembatasan sosial berskala besar (PSBB), berbeda dengan desa yang digenjot perekonomiannya, terus berjalan dengan realokasi stimulus fiskal. Sekarang, desa menghadapi Covid-19 dengan dua penguatan dari pemerintah, yakni penguatan pembangunan desa untuk kegiatan Padat Karya Tunai Desa (PKTD) dan penguatan kesehatan masyarakat.

\section{Kesimpulan}

Partisipasi bisa dihasilkan melalui proses pemaksaan, namun pada akhirnya akan menghilangkan arti partisipasi itu sendiri. Partisipasi masyarakat yang baik dalam penanganan penyebaran Covid-19 tentu dilakukan dengan sukarela, karena merasa masing-masing individu mempunyai tanggung jawab untuk kepentingan bersama. Pemerintah tidak bisa bekerja sendirian, tetapi memerlukan partisipasi dari semua komponen masyarakat, termasuk tokoh agama, tokoh masyarakat dan Lembaga masyarakat lainnya. Partisipasi masyarakat dalam menangani penyebaran Covid-19 sangat diperlukan, 
yakni dengan mengikuti aturan yang ditetapkan pemerintah pusat dan pemerintah daerah seperti tetap di rumah, menjaga jarak, menggunakan masker, rajin cuci tangan dan menerapkan pola hidup sehat. Hal ini perlu dilakukan guna memutus mata rantai penularan dan penyebaran Covid19. DPR RI perlu segera mendorong pemerintah untuk bersama-sama melakukan revisi terhadap UU No. 4 Tahun 1984 tentang Wabah Penyakit Menular, karena undang-undang ini tampaknya sudah tidak sesuai dengan kondisi yang berkembang di mana penanganan wabah penyakit semakin rumit sehingga ada beberapa dimensi yang harus disesuaikan.

\section{Daftar Pustaka}

Ali Hanapiah Muhi. 2011. Fenomena Pembangunan Desa. Jatinangor, Jawa Barat: Institut Pemerintahan Dalam Negeri.

Arif Budiman. 2000. Teori Pembangunan

Dunia ke Tiga. Jakarta: Gramedia Pustaka.

B. Herry \& Priyono. 2002. Anthony Giddens Suatu Pengantar. Jakarta: KPG Kepustakaan Populer Gramedia.

Diani Budiarto, dkk. 2005. Perspektif Pemerintahan Daerah Otonomi,
Birokrasi, dan Pelayanan Publik. Bogor: Fisip Universitas Djuanda.

Eko A. Meinarno, dkk. 2011. Manusia dalam Kebudayaan dan Masyarakat. Jakarta: Salemba Humanika.

Eko Murdiyanto. 2008. Sosiologi Pedesaan. Yogyakarta: Wimaya Press UPN "Veteran".

Elly M. Setiadi dan Usman Kolip. 2011. Pengantar Sosiologi: Pemahaman Fakta dan Gejala Permasalahan Sosial. Jakarta: Kencana.

Elly M. Setiadi. 2011. Pengantar Sosiologi. Jakarta: Kencana.

Fahd Pahdepie dkk. 2006. Pemberdayaan Ekonomi Berbasis Umat. Bandung: Sekda Provinsi Jabar.

George Ritzer dan Douglas J. Goodman. 2010. Teori Sosiologi Modern. Jakarta: Kencana.

Keesing. 2014. Kin Groups and Social Structure. Philadelphia: Harcort Brace Jovanovich College Publisher.

Rahardjo. 1999. Pengantar Sosiologi Pedesaan dan Sosiologi Pertanian. Yogyakarta: UGM Press.

Sondang P.Siagian. 2000. Manajemen Strategik. Jakarta : PT Bumi Aksara. 